\title{
Telomere Attrition and Clonal Hematopoiesis of Indeterminate Potential in Cardiovascular Disease
}

\author{
Yi-Chun Huang ${ }^{1}$ (D) and Chao-Yung Wang ${ }^{1,2,3,4, *}$ \\ 1 Division of Cardiology, Chang Gung Memorial Hospital, Linkou Medical Center, Taoyuan City 33305, Taiwan; \\ twkodesamurai@gmail.com \\ 2 School of Medicine, College of Medicine, Chang Gung University, Taoyuan City 33302, Taiwan \\ 3 Institute of Cellular and System Medicine, National Health Research Institutes, Zhunan 35053, Taiwan \\ 4 Department of Medical Science, National Tsing Hua University, Hsinchu 30013, Taiwan \\ * Correspondence: cwang@ocean.ag
}

Citation: Huang, Y.-C.; Wang, C.-Y. Telomere Attrition and Clonal Hematopoiesis of Indeterminate Potential in Cardiovascular Disease. Int. J. Mol. Sci. 2021, 22, 9867 .

https://doi.org/10.3390/ijms22189867

Academic Editor: Cristina Banfi

Received: 13 July 2021

Accepted: 9 September 2021

Published: 13 September 2021

Publisher's Note: MDPI stays neutral with regard to jurisdictional claims in published maps and institutional affiliations.

Copyright: (c) 2021 by the authors. Licensee MDPI, Basel, Switzerland. This article is an open access article distributed under the terms and conditions of the Creative Commons Attribution (CC BY) license (https:// creativecommons.org/licenses/by/ $4.0 /)$
Abstract: Clinical evidence suggests that conventional cardiovascular disease (CVD) risk factors cannot explain all CVD incidences. Recent studies have shown that telomere attrition, clonal hematopoiesis of indeterminate potential (CHIP), and atherosclerosis (telomere-CHIP-atherosclerosis, TCA) evolve to play a crucial role in CVD. Telomere dynamics and telomerase have an important relationship with age-related CVD. Telomere attrition is associated with CHIP. CHIP is commonly observed in elderly patients. It is characterized by an increase in blood cell clones with somatic mutations, resulting in an increased risk of hematological cancer and atherosclerotic CVD. The most common gene mutations are DNA methyltransferase 3 alpha (DNMT3A), Tet methylcytosine dioxygenase 2 (TET2), and additional sex combs-like 1 (ASXL1). Telomeres, CHIP, and atherosclerosis increase chronic inflammation and proinflammatory cytokine expression. Currently, their epidemiology and detailed mechanisms related to the TCA axis remain incompletely understood. In this article, we reviewed recent research results regarding the development of telomeres and CHIP and their relationship with atherosclerotic CVD.

Keywords: atherosclerosis; clonal hematopoiesis of indeterminate potential; telomere; TCA axis

\section{Introduction}

With age, genomic instability and acquired somatic mutations of hematopoietic stem cells (HSCs) gradually occur, and some clones disproportionately occupy the bone marrow and peripheral blood cells. The clonal expansion of mutant cells is associated with increased risk of hematologic disease [1]. People with increased blood cell clones without hematological malignancy are considered to have clonal hematopoiesis of indeterminate potential (CHIP). CHIP is defined as somatic mutations of a leukemia-associated gene with variant allele frequency $(\mathrm{VAF}) \geq 2 \%$, normal peripheral blood counts, and no clinical or pathological evidence of World Health Organization (WHO)-defined hematologic malignancy neoplasm [2]. CHIP was observed in $>10 \%$ of people aged $>70$ years [3]. Age-related CHIP is associated with an increase in hematologic cancer risk, and people with CHIP have high all-cause mortality. The increased mortality risk is mostly due to increased cardiovascular diseases (CVDs) [3]. The exact mechanism by which CHIP leads to high CVD occurrence is under investigation. According to current research, chronic inflammation through several specific pathways may be crucial mechanisms of CHIP-related atherosclerosis [4]. Targeting these specific inflammatory pathways may be the focus of future research.

Telomeres are double-stranded repeats of G-rich tandem DNA sequences that gradually shorten with each cell division. The main function of telomeres is to protect crucial genetic information in the cell from being lost during cell division. Each time the cell divides, the ends of the chromosomes shorten by 25-200 bases [5-7]. Because telomeres 
protect the terminal regions of chromosomal DNA, the telomeres ensure the retention of crucial genetic information even after cell division. As the cell undergoes multiple divisions, the telomere length decreases. When the telomere reaches a critical length, the cell can no longer divide, and undergoes the physiological mechanism of cellular senescence. Telomerase can synthesize DNA end sequences and extend telomeres, playing an important role in maintaining telomere dynamics and preventing DNA damage. Recent studies have shown that inflammation, oxidative stress, and age accelerate telomere shortening [8-10]. Telomere shortening and telomerase dysfunction both play crucial roles in the pathophysiological mechanism of aging-associated CVD [11-13]. Telomere therapy for CVD became popular because of population aging and growing evidence of the role of telomere dysfunction in cardiovascular physiology [14].

Cardiovascular treatments focus on traditional cardiovascular risk factors, which include hypertension, diabetes, smoking, dyslipidemia, and obesity. However, many patients develop CVDs despite the absence of these traditional risk factors [15-19]. Thus, our understanding of CVD pathophysiology remains incomplete. Clinical observations have revealed significant associations between decrease in telomere length and increase in CHIP. Both these phenomena are related to increased CVD risk. CHIP is an independent risk factor for CVD. Furthermore, studies have suggested that the manipulation of telomeres and telomerase is a treatment strategy for CVD. Moreover, telomere dynamics may play a role in CHIP development [20-22]. This review focuses on the current evidence supporting the relationships between telomeres, CHIP, and CVD.

\section{Telomere and Telomerase in CVD}

A telomere is a repetitive sequence (TTAGGG)n located at the end of the chromosomal DNA of eukaryotic cells. The functions of telomeres and telomerase involve ensuring the complete replication of chromosomal DNA and prevention of chromosomal end damage. Telomerase consists of a telomerase RNA component (TERC) and a catalytic telomerase enzyme reverse transcriptase (TERT) [5]. Telomerase stabilizes telomere length. Telomerase activity is precisely controlled through multiple mechanisms, which ensure adequate telomere length homeostasis [23]. Although the telomere length varies by individual, the length of the human telomere is approximately $10-15 \mathrm{~kb}$. At each cell division, the telomere DNA shortens by $50-100$ base pairs due to incomplete replication at the $3^{\prime}$ end. This mechanism leads to telomere shortening [6]. When the telomere is shortened to a critical point, genomic instability occurs and the DNA repair system is activated to cause replicative arrest, senescence, and cell death $[8,24,25]$. By contrast, increased telomere length is associated with the risk of various cancers $[26,27]$. Telomere length varies slightly among different tissues [28,29]. Peripheral leukocyte telomere length (LTL) can be easily determined in humans and is significantly associated with immunologic system aging and CVD risk, irrespective of traditional risk factors [30,31]. LTL gradually shortens with age and is considered the biological molecular clock [32]. At present, many detection methods are available for detecting telomere length. Among them, quantitative polymerase chain reaction (PCR) is a high-throughput and low-cost method. It only generates the mean telomere length without providing the telomere length distribution in the DNA sample. The single telomere length analysis and telomere shortest length assay are relatively new methods of measuring single-telomere data based on a combination of PCR and Southern blot [33,34].

Many large epidemiological studies have supported the relationship between telomere length and CVD $[12,13,35,36]$. CVD and telomere shortening have many common risk factors, including diabetes mellitus, hypertension, dyslipidemia, obesity, and smoking. Furthermore, excessive oxidative stress and chronic inflammation are important factors that contribute to telomere shortening and CVD [37,38]. In addition, disrupted circadian rhythm has been confirmed to shorten telomere length and increase CVD risk [39-42]. Moreover, diets high in omega-3 fatty acid [43] and lifestyle modification with exercise [44,45] can reduce the rates of telomere shortening and CVD. In addition to these common risk factors 
for telomere length shortening and CVD, current clinical evidence suggests that telomeres play a crucial role in atherosclerotic CVD (Figure 1). The West of Scotland Coronary Prevention Study (WOSCOPS) showed that the mean LTL is a predictor of future coronary heart disease. In WOSCOPS, the mean telomere length decreased with age by $9 \%$ per decade. Individuals in the lowest tertiles of LTL had almost two times the risk of coronary artery events compared with those in the highest tertiles (WOSCOPS) [12]. In 2014, a meta-analysis of 24 prospective and retrospective studies that included 43,725 participants revealed that a shorter LTL is associated with a pooled relative risk of coronary heart disease of 1.54 compared with a longer LTL [13]. Virtual histology intravascular ultrasound revealed that increased proinflammatory activity in high-risk unstable plaque frequently occurs in patients with short LTL [46]. Moreover, a small clinical study demonstrated through optical coherence tomography that a shorter LTL indicated a higher percentage of uncovered stent struts [47]. Furthermore, telomere length is shorter than usual in patients with congestive heart failure [48,49]. In a study involving 620 patients with congestive heart failure, the relative telomere length was nearly $60 \%$ that of the normal participants and was significantly correlated with their New York Heart Association function class status [50].

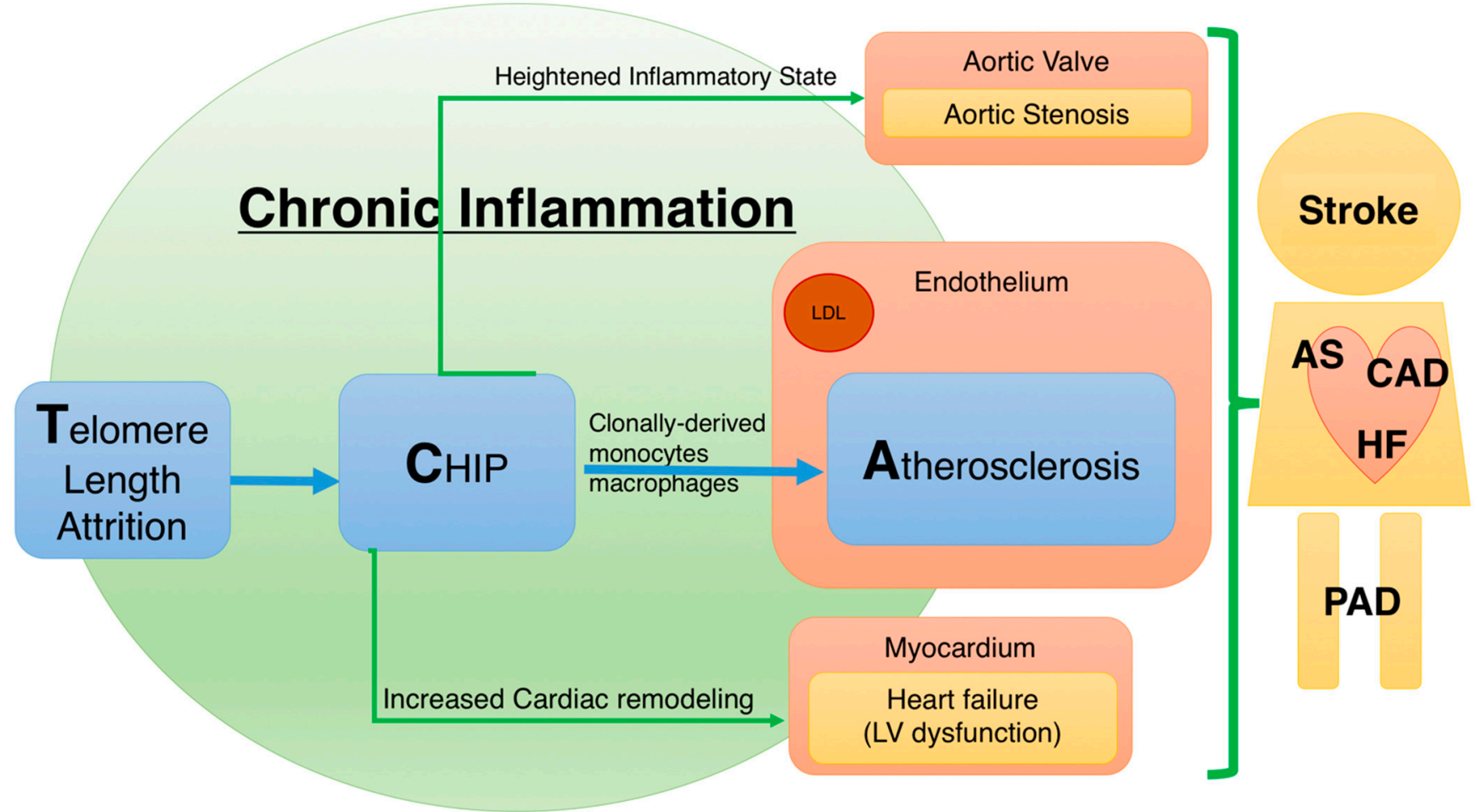

Figure 1. Telomere-CHIP-atherosclerosis (TCA) axis and cardiovascular disease. The TCA axis represents a novel cardiovascular treatment target in addition to traditional risk factors. With aging and telomere length attrition, hematopoietic stem cells develop clonal hematopoiesis of indeterminate potential (CHIP). CHIP then further aggravates chronic inflammation through multiple CHIP-related mutant gene signaling pathways, including Tet methylcytosine dioxygenase 2 (TET2), additional sex combs-like 1 (ASXL1), Janus kinase 2 (JAK2), and DNA methyltransferase 3 alpha (DNMT3A). The affected cells, including macrophages, mast cells, and T cells, further increase the risk of atherosclerosis, coronary artery disease (CAD), aortic stenosis (AS), heart failure (HF), and possibly peripheral arterial occlusive diseases (PAD).

Studies have shown that mice with genetic TERC or TERT knockout have progressively shorter telomeres with the pathophysiological phenomena of cardiovascular dysfunction, aging, and early death. Telomere shortening in late-generation TERC knockout mice results in decreased cardiomyocyte proliferation, cardiac dilatation, and heart failure with p53 upregulation [48]. These cardiac changes can be delayed through telomerase 
re-expression [51]. Telomere shortening results in immune cell dysfunction and chronic inflammation [52,53]. In TERC- or TERT-knockout mice, proinflammatory cytokines including interleukin (IL)-6, chemokine (C-X-C motif) ligand 16, and tumor necrosis factor- $\alpha$ are enhanced [54]. Moreover, increased inflammation and atherosclerosis are observed in late-generation TERT or TERC knockout mice. Chronic inflammation further increases oxidative stress and induces telomere dysfunction $[37,38]$. Although there is already abundant evidence to support the relationship between the telomere system and chronic inflammation in the cardiovascular system. There are still several studies that argue against this possibility. Past studies have shown that telomere attrition as a mechanism for restricting atheroma progression in hypercholesterolemic mice [55]. Some people have reorganized the current evidence and various experiments to question the causal relationship between telomere attrition and CVD is not clear enough [56]. More research focusing on this direct connection is needed in the future.

Experimental therapies targeting telomeres or telomerase in mice have shown promising results in CVDs. Telomerase gene therapy was first achieved through delivering mouse TERT with an adeno-associated virus into young and old mice. In the experiment, elongated telomeres, extended lifespans, and delayed age-associated pathologies were observed in both the age groups. The treatment group with the TERT adeno-associated virus did not have higher cancer incidences than those of the placebo group [57]. Using this $T E R T$ adeno-associated technique in mice with myocardial infarction conferred significant cardioprotection with less cardiac dilation, improved ventricular function, and smaller infarct scars compared with the control group [58]. The modified messenger RNA encoding TERT delivered in human fibroblasts also temporarily increases telomerase activity and extends telomere length. Research on the clinical impacts of telomere therapy on myocardial infarction is still in progress [59].

Some drugs used in CVD treatment are related to the regulation of telomerase activity. Statins (3-hydroxy-3-methylglutaryl coenzyme A reductase inhibitors) can prevent atherosclerotic plaque formation through multiple mechanisms [60]. A cross-sectional analysis of data from the U.S. National Health and Nutrition and Nutrition Examination Survey 1999-2002 showed that statin use for extended periods may be associated with an increase in telomere length [61]. Furthermore, statins can increase telomerase through the adjustment of the TRF2 of endothelial cells and activity of endothelial progenitor cells (EPCs) [62]. Telomere repeat binding factor 2(TRF2) is part of the Shelterin complex used to protect telomeres and regulate telomerase activity. Both angiotensin II receptor blockers and angiotensin-converting enzyme inhibitors can protect EPCs from senescence and dysfunction through telomere crosstalk $[63,64]$. However, whether using these drugs in actual clinical practice can slow telomere shortening requires further research [65]. In an animal experiment, peroxisome proliferator-activated receptor agonists (PPARs, e.g., pioglitazone) increased telomerase activity and TRF2 expression [66]. Moreover, PPARs has shown to reduce senescence markers, p16, cell-cycle checkpoint kinase 2, and p53 [67,68]. TA-65, a bioactive molecule extracted from Astragalus membranaceus, is regarded a lowpotency telomerase activator [69]. Randomized, double-blind, and placebo-controlled clinical trials have shown that TA-65 treatment increases high-density lipoprotein cholesterol and reduces c-reactive protein in patients with metabolic syndrome and elongates telomeres [70,71]. Sex hormones are believed to activate TERT transcription. In the past, the mechanism by which androgen therapy can be used in aplastic anemia has been unclear, but reports have indicated that androgen-induced effects are achieved through upregulated telomerase activity $[72,73]$.

\section{Relationships between CHIP and CVDs}

Clonal hematopoiesis is an aging phenomenon in the hematologic system. Aging is associated with increases in somatic mutations in many tissues, including the spontaneous deamination of 5-methylcytosine, insertions and deletions, replication errors with base changes, and large structural variations. Considering that the somatic mutation rate of each 
HSC is one exonic mutation per decade of life, a 70-year-old person would have a significant number of mutations per gene. According to natural selection, HSCs or blood progenitor cells acquiring certain somatic mutations with aging will form a genetically distinct clone of blood cells. If the clone does not overgrow to form hematologic malignancies, it will persist in aged people and become prevalent. A similar phenomenon was observed in the skin and esophagus [74,75].

Clonal hematopoiesis prevalence increases with age. In healthy individuals $<40$ years old, the somatic mutation clone prevalence is $<1 \%$. In individuals aged $>70$ years, $>10 \%$ have a detectable clone. The percentage of these mutated clones varies from $0.01 \%$ to $>18 \%$ depending on the detection methods used in clinical trials [3,75]. However, for determining the clinical impact of the clonal percentage, further investigations are required. Currently, no evidence supports that a larger clonal size corresponds to higher physiological disruption or changes.

Multiple studies have shown that CHIP is associated with a $>30 \%$ increase in mortality risk. The increase in CHIP-related mortality is not due to cancer but to the increase in cardiovascular events $[1,3,76]$. Nested case-control analyses of two prospective cohorts revealed that CHIP carriers had nearly twice the risk of early myocardial infarction and stroke compared with noncarriers [77]. Another retrospective case-control study showed that individuals $<50$ years old with CHIP have a four times higher risk of early-onset myocardial infarction [78-80]. Moreover, higher VAF and CHIP are associated with coronary artery calcification [77]. VAF is the percentage of sequence reads observed matching a specific DNA variant divided by the overall coverage at that locus. Clinically, because NGS provides a near random sample, VAF is thus a surrogate measure of the proportion of DNA molecules in the original specimen carrying the variant [81]. In patients with congestive heart failure, CHIP is associated with the progression and poor prognosis of congestive heart failure. For patients with ischemic heart failure and reduced left ventricular ejection fraction, the presence of CHIP is associated with adverse outcomes and increased cardiovascular events [82,83]. In some registry data, certain percentage of heart failure patients whose cause of death is related to hematologic cancer. Some studies also show that patients with advanced heart failure prone to develop cancers. This implies that we should have further research on the relationship of abnormal heart function, CHIP, and tumor growth $[84,85]$. Moreover, clonal hematopoiesis plays an important role in another age-associated disease, severe aortic stenosis. Patients of all age groups with severe aortic stenosis have considerably higher CHIP. Among 279 patients undergoing transcatheter aortic valve implantation (TAVI), somatic DNA methyltransferase 3 alpha (DNMT3A) or Tet methylcytosine dioxygenase 2 (TET2) CHIP-driver mutations were detected in 93 out of 279 patients (33.3\%). These patients with CHIP were associated with increased mortality in the first 8 months after TAVI [86]. More than 100 mutation driver genes are associated with CHIP. The most common mutations observed are DNMT3A, TET2, and ASXL1. Although $J A K 2$ mutation is relatively less common, it has a disproportionate impact on the risk of CVD in clinical practice. (Figure 2) [76,87]. TET2 is a multifaceted transcriptional regulator that can promote both transcriptional activation and repression according to the molecular and cytological environment. In mice, TET2-deficient bone marrow-transplanted cells expanded in the blood and accelerated atherosclerosis. Myeloid-specific TET2 ablation is sufficient to promote atherosclerosis, indicating that macrophages play a role in these TET2-deficient cells [88]. Moreover, TET2 deficiency in mice aggravated heart failure and exacerbated pathological cardiac remodeling $[89,90]$. TET2 mutation associated clonal hematopoiesis is also reported to aggravates insulin resistance in mice, establishing a causal relationship between TET2 mutation and type 2 diabetes mellitus [91]. Enhanced atherosclerosis with TET2 deficiency in macrophages is mediated through increasing proinflammatory signaling, including IL- $1 \beta$, IL-6, and NOD-, LRR-, and the pyrin domaincontaining protein 3 (NLRP3) inflammasome complex [92]. TET2 deficiency contributes to IL-1 $\beta$ production in macrophages through NLRP3 enhancement. An experiment with mice revealed that pharmacological blockade of NLRP3 inflammasome-mediated IL-1 $\beta$ 
secretion increased atheroprotective effects [88]. The association between IL-1 $\beta$ overproduction by TET2 mutation and increased atherosclerosis is supported by the results of the Canakinumab Anti-Inflammatory Thrombosis Outcomes Study (CANTOS) trial. In the CANTOS trial, IL-1 $\beta$ blockade significantly reduced recurrent cardiovascular events in patients with previous myocardial infarction $[93,94]$. The role of the IL-1 $\beta$ monoclonal antibody in reducing cardiovascular events is independent of lipid-level reduction. A similar concept, whereby anti-inflammatory therapy can improve cardiovascular outcomes, has been supported in studies related to colchicine. In 2019, a randomized and doubleblind trial, including 4745 patients with recent myocardial infarction, showed that a low dose of colchicine can effectively reduce ischemic cardiovascular events compared with a placebo [95].

\section{Anti-Inflammation Compounds (Colchicine)}

\section{Chronic (Systemic) Inflammation}

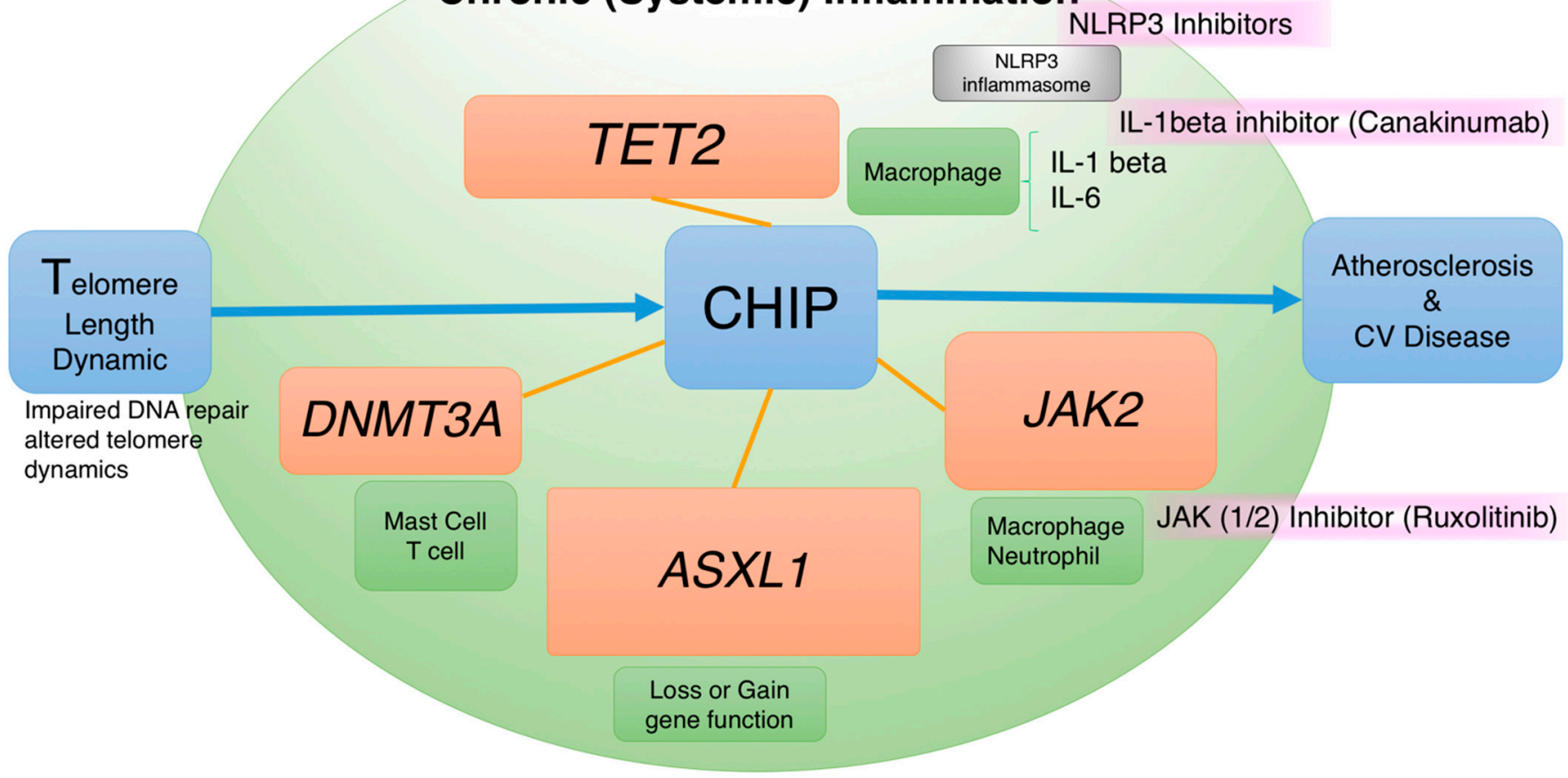

Figure 2. Telomere-CHIP-atherosclerosis (TCA) axis, somatic mutations, and potential therapeutic options. Four major mutant genes identified in patients with CHIP, namely TET2, ASXL1, JAK2, and DNMT3A. Here, we highlight the possible therapeutic compounds targeting each $\mathrm{CHIP-related} \mathrm{mutant} \mathrm{gene} \mathrm{pathway.} \mathrm{The} \mathrm{general} \mathrm{anti-inflammatory} \mathrm{agents}$ are colchicine, TET2-related NOD-, LRR-, and pyrin domain-containing protein 3 (NLRP3) inhibitors targeting NLRP3 inflammasome, IL-1 $\beta$ inhibitor (canakinumab), and JAK2-related JAK(1/2) inhibitor (ruxolitinib).

DNMT3A deficiency of bone marrow-transplanted cells is also associated with increased cardiac fibrosis and worse cardiac function following angiotensin II infusion. $D N M T 3 A$ augments inflammatory pathways involving macrophage accumulation in the heart and proinflammatory molecules IL-6 and CXCL5 [96]. DNMT3A plays a crucial role in modulating mast cell responses [97]. Furthermore, $D N M T 3 A$ is a T-cell receptor-related regulator of Th1 and Th2 differentiation and is involved in interferon- $\gamma$ expression [98]. Recent studies have also mentioned that circulating monocytes and $\mathrm{T}$ cells in heart failure patients may cause aggravation of the inflammatory response and worsen chronic heart failure [99].

$J A K 2$ is a tyrosine kinase which mainly plays a role in signaling transmission. It is found in patients with polycythemia vera and essential thrombocytopenia [100]. Such patients have a high risk of thrombosis and CVD. JAK2 is involved in erythropoietin and thrombopoietin pathways [101-103]. Mice receiving JAK2 mutant bone marrow transplant 
cells develop accelerated heart failure [104]. JAK2 mutation showed increased expression of absent in melanoma 2 (AIM2), DNA replication stress, oxidative DNA damage, and multiple inflammatory pathway, thereby aggravating atherosclerosis [105-107]. Clinically, a JAK1 2 inhibitor, ruxolitinib, was proven to be helpful in controlling hematocrit, reducing spleen volume, and improving symptoms in patients with polycythemia vera compared with the standard treatment [108]. Adequate hematocrit control significantly reduces cardiovascular death and major thrombosis [109]. Clinical evidence suggests that JAK1/2 inhibitor is a potential therapeutic target, and it deserves more specific research in the future.

ASXL1 mutation in mouse HSCs induces age-related expansion through overactive Akt/mammalian target of rapamycin (mTOR) signaling. ASXL1 cooperates with its partner protein BAP1 to deubiquitinate and activate Akt. The mTOR inhibitor rapamycin, which has previously been shown to prolong murine life span, ameliorates dysregulated hematopoiesis in aged ASXL1 mutant mice [110,111].

Although the association between gene mutations and CHIP has been established, a large knowledge gap exists regarding the detailed molecular biological mechanism. The exact impact of CHIP on human health is still under intense investigation. The scientific debate on directionality in the association between clonal hematopoiesis and CVD is still ongoing. Through mathematical models, some studies have pointed out that perhaps reverse causality (that is, atherosclerosis accelerates clonal hematopoiesis) could explain the clonal hematopoiesis-CVD association [112]. Several ongoing studies focused on CHIP treatment will reveal the potential clinical impact of CHIP. First, chronic IL-1 drives HSCs toward precocious myeloid differentiation, whereas TET2 mutation may lead to IL-1 overproduction. Whether IL-1 blockade can reverse or limit clonal expansion is critical in future cardiovascular therapeutic road maps $[93,94]$. Research has been focused on the role of metabolism and several metabolites in CHIP development and treatment. In mouse experiments, vitamin C restored TET2 activity in HSCs [113]. Crosstalk between the immune system and metabolism during CHIP development and atherosclerosis is also an intensely studied field. Many large-scale studies on the clinical impact of CHIP are underway to understand CHIP and related diseases and identify the specific gene mutation and associated disease development. Several prospective cohort studies on CHIP analyses are ongoing, including the Atherosclerosis Risk in Communities Study and UK Biobank [114-117]. These analyses will help us to identify the dose-response relationship between CHIP clone size and its effect on atherosclerotic CVD. The relationships between $\mathrm{CHIP}$ and other age-related diseases are also under investigation. For example, Alzheimer's disease and related cognitive decline are being studied to determine whether CHIP plays a significant role in these diseases [118,119].

Despite strong evidence supporting the importance of CHIP in cardiovascular patients, no clear guideline suggests when and how to test CHIP in patients. We reasoned that several factors can be considered to study CHIP. First, in patients $>65$ years old with coronary artery disease or acute coronary syndrome, no traditional risk factors or earlyonset CVD were observed. Second, identified CHIP mutations will affect clinical decisions. For example, in patients with TET2 mutation and IL- $1 \beta$ mutation, IL-1 $\beta$ blockade may serve as a viable therapeutic agent. Third, future clinical trials may confirm that CHIP clone sizes are related to cardiovascular risks. In addition to the traditional risk factors, the CHIP clone sizes and CHIP-related genes can be considered CV risk factors. These clinically important issues urgently require more research and evidence to guide decision making.

Currently, diagnosing and surveilling CHIP pose a clinical challenge for both patients and cardiologists. CHIP is detected through elective whole-genome sequencing during clinical trials, genome sequencing for studying cardiovascular traditional risks, genome sequencing in organ donors, or a hematologic or solid tumor. Strategic and systemic evaluations of cost-effective methods for CHIP detection will be required in the future. 


\section{Telomere-CHIP-Atherosclerosis Related Pathway}

The Framingham Study that began in 1948 advanced our understanding on standard modifiable cardiovascular risk factors [120] (SMuRFs; hypertension, diabetes, hypercholesterolemia, and smoking). In the past few decades, research and treatment related to these traditional factors have been successful. However, even after these risk factors have been corrected and improved clinically, mortality trends remain steady in many countries. Many patients with CVDs have no identifiable traditional cardiovascular risk factors. This observation implies that blind spots remain in understanding of CVDs. Cancer and CVDs are the two main causes of mortality in the general population, and their incidences increase with age $[15-19,121]$. Their mutual association is gradually being recognized through CHIP and telomere signaling.

Genetic association studies have repeatedly shown that CHIP has polygenic and inherited risk [122]. Its associations with the TERT locus have been replicated in numerous clinical trials. Clonal hematopoiesis is strongly correlated with mosaic loss of the $\mathrm{Y}$ chromosome, which indicates a significant association between telomere biology and CHIP [76]. After high-coverage whole-genome sequences from 97,691 participants with 4229 individuals with CHIP were analyzed, a common germline variant in the TERT intron was identified to be significantly associated with CHIP. This result highlights the importance of telomere and telomerase function, which can shape somatic variation in HSCs. Other whole-genome sequencing and genome-wide association studies have revealed that CHIP carriers have a relatively short LTL and often carry a genetic variant of the related telomerase gene [123]. Dyskeratosis congenita is a rare inherited disease and a short telomere syndrome. Other diseases considered to be short telomere syndromes include Hoyeraal-Hreidarsson syndrome, Revesz syndrome, cerebroretinal microangiopathy with calcifications and cysts, aplastic anemia, and Fanconi anemia. Short telomere syndromes, also known as telomeropathies, are characterized by genetic mutations leading to shortened telomere length, which ultimately leads to accelerated cell turnover and disease in multiple organs. Organs that are often involved include the skin, bone marrow, lungs, and gastrointestinal tract $[124,125]$. Clonal hematopoiesis in people with short telomere syndromes is common. The majority of patients with dyskeratosis congenita have clonal hematopoiesis, as evidenced through skewed X-inactivation [126].

Aging, as well as exposure to various environmental factors including radiation, smoking, and air pollution, results in gradual leukocyte telomere attrition [127]. Telomere shortening and telomerase dysfunction can lead to genomic instability and ultimately to CHIP. Currently, clinical evidence supports the relationship between telomere dysfunction and CHIP. However, the direct association between telomere attrition and CHIP must be confirmed with more in-depth research. Moreover, how CHIP interacts with the complex physiology of atherosclerosis is still a subject for more comprehensive study. The telomereCHIP-atherosclerosis (TCA) axis (Figure 1) is a new and evolving concept. There are still very limited data on the interplay between telomere biology and clonal hematopoiesis. Accumulating evidence will reveal that whether therapeutics targeting the TCA axis will further protect cardiovascular patients. Elderly patients without traditional risk factors would benefit the most from TCA-related therapy in future [21].

\section{Conclusions}

In the past 10 years, understanding and treatment of CVD have been constantly evolving. Both drugs and interventional treatments have advanced significantly. However, overall outcome improvement has stagnated. Moreover, some patients are unable to receive precise and personalized preventive treatment because they do not have SMuRFs. CHIP emergence and the discovery of its association with the TCA axis provide a new direction for cardiological research. Furthermore, this new concept solves many problems. The limited understanding of detailed mechanisms involved in CHIP makes appropriate risk stratification of patients with CHIP difficult. Furthermore, the optimal method of properly monitoring and following up with patients with CHIP is unknown. Behavioral, lifestyle, 
environmental, and heritable factors that affect CHIP remain unclear. More cellular or animal model studies are warranted to simulate the gradual and long-term processes of telomere attrition and increase understanding of TCA signaling.

Author Contributions: Y.-C.H. and C.-Y.W. drafted the manuscript. C.-Y.W. edited the manuscript. Y.-C.H. and C.-Y.W. designed and made the figures. Y.-C.H. and C.-Y.W. confirmed the final version of the manuscript. All authors have read and agreed to the published version of the manuscript.

Funding: Chao-Yung Wang received support from the National Health Research Institute (NHRIEX10610617SI, NHRI-110A1-CSCO-17212418), National Science Council (105-2628-B-182-009-MY4 and 109-2314-B-182-070-MY3), and Chang Gung Memorial Hospital (CMRPG3H0133, CMRPG3I0323, CMRPG3H0843, and CMRPG3L0871).

Institutional Review Board Statement: Not applicable.

Informed Consent Statement: Not applicable.

Data Availability Statement: Not applicable.

Acknowledgments: The authors thank Mei-Hsiu Lin, Tsu-Hui Yeh, Ko-Chiang Chou, Yu-Chun Chuang, and Hsiao-Chien Huang for technical assistance.

Conflicts of Interest: The authors declare no conflict of interest.

$\begin{array}{ll}\text { Abbreviations } \\ \text { AIM2 } & \begin{array}{l}\text { absent in melanoma } 2 \\ \text { additional sex combs-like-1 }\end{array} \\ \text { ASXL1 } & \text { Canakinumab Anti-Inflammatory Thrombosis Outcomes Study } \\ \text { CANTOS } & \text { Clonal hematopoiesis of indetermenate potential } \\ \text { CHIP } & \text { Cardiovascular disease } \\ \text { CVD } & \text { DNA methyltransferase } 3 \text { alpha } \\ \text { DNMT3A } & \text { Endothelial progenitor cells } \\ \text { EPCs } & \text { hematopoietic stem cells } \\ \text { HSCs } & \text { Leukocyte telomere length } \\ \text { LTL } & \text { NOD-, LRR-, and the pyrin domain-containing protein 3 } \\ \text { NLRP3 } & \text { Peroxisome proliferator-activated receptor agnoists } \\ \text { PPARs } & \text { Standard modifiable cardiovascular risk factors } \\ \text { SMuRFs } & \text { Transcatheter aortic valve implantation } \\ \text { TAVI } & \text { Telomere-CHIP-atherosclerosis } \\ \text { TCA } & \text { Telomerase consists of a telomerase RNA component } \\ \text { TERC } & \text { Telomere length homeostasis } \\ \text { TERT } & \text { Tet methylcytosine dioxygenase 2 } \\ \text { TET2 } & \text { Telomere repeat binding factor 2 } \\ \text { TRF2 } & \text { variant allele frequency } \\ \text { VAF } & \text { World Health Organization } \\ \text { WHO } & \text { The West of Scotland Coronary Prevention Study } \\ \text { WOSCOPS } & \end{array}$

\section{References}

1. Genovese, G.; Kahler, A.K.; Handsaker, R.E.; Lindberg, J.; Rose, S.A.; Bakhoum, S.F.; Chambert, K.; Mick, E.; Neale, B.M.; Fromer, M.; et al. Clonal hematopoiesis and blood-cancer risk inferred from blood DNA sequence. N. Engl. J. Med. 2014, 371, 2477-2487. [CrossRef]

2. Steensma, D.P.; Bejar, R.; Jaiswal, S.; Lindsley, R.C.; Sekeres, M.A.; Hasserjian, R.P.; Ebert, B.L. Clonal hematopoiesis of indeterminate potential and its distinction from myelodysplastic syndromes. Blood 2015, 126, 9-16. [CrossRef]

3. Jaiswal, S.; Fontanillas, P.; Flannick, J.; Manning, A.; Grauman, P.V.; Mar, B.G.; Lindsley, R.C.; Mermel, C.H.; Burtt, N.; Chavez, A.; et al. Age-related clonal hematopoiesis associated with adverse outcomes. N. Engl. J. Med. 2014, 371, 2488-2498. [CrossRef]

4. Soehnlein, O.; Libby, P. Targeting inflammation in atherosclerosis-From experimental insights to the clinic. Nat. Rev. Drug Discov. 2021, 20, 1-22. [CrossRef]

5. Chan, S.R.; Blackburn, E.H. Telomeres and telomerase. Philos. Trans. R Soc. Lond. B Biol. Sci. 2004, 359, 109-121. [CrossRef]

6. O'Sullivan, R.J.; Karlseder, J. Telomeres: Protecting chromosomes against genome instability. Nat. Rev. Mol. Cell Biol. 2010, 11, 171-181. [CrossRef] 
7. d'Adda di Fagagna, F. Living on a break: Cellular senescence as a DNA-damage response. Nat. Rev. Cancer 2008, 8, 512-522. [CrossRef]

8. Aubert, G.; Lansdorp, P.M. Telomeres and aging. Physiol. Rev. 2008, 88, 557-579. [CrossRef]

9. Jurk, D.; Wilson, C.; Passos, J.F.; Oakley, F.; Correia-Melo, C.; Greaves, L.; Saretzki, G.; Fox, C.; Lawless, C.; Anderson, R.; et al. Chronic inflammation induces telomere dysfunction and accelerates ageing in mice. Nat. Commun. 2014, 2, 4172. [CrossRef]

10. Zhang, J.; Rane, G.; Dai, X.; Shanmugam, M.K.; Arfuso, F.; Samy, R.P.; Lai, M.K.; Kappei, D.; Kumar, A.P.; Sethi, G. Ageing and the telomere connection: An intimate relationship with inflammation. Ageing Res. Rev. 2016, 25, 55-69. [CrossRef]

11. Samani, N.J.; Boultby, R.; Butler, R.; Thompson, J.R.; Goodall, A.H. Telomere shortening in atherosclerosis. Lancet 2001, 358, 472-473. [CrossRef]

12. Brouilette, S.W.; Moore, J.S.; McMahon, A.D.; Thompson, J.R.; Ford, I.; Shepherd, J.; Packard, C.J.; Samani, N.J. Telomere length, risk of coronary heart disease, and statin treatment in the West of Scotland Primary Prevention Study: A nested case-control study. Lancet 2007, 369, 107-114. [CrossRef]

13. Haycock, P.C.; Heydon, E.E.; Kaptoge, S.; Butterworth, A.S.; Thompson, A.; Willeit, P. Leucocyte telomere length and risk of cardiovascular disease: Systematic review and meta-analysis. BMJ 2014, 349, g4227. [CrossRef]

14. Yeh, J.K.; Lin, M.H.; Wang, C.Y. Telomeres as Therapeutic Targets in Heart Disease. JACC Basic Transl. Sci. 2019, 4, 855-865. [CrossRef] [PubMed]

15. Vernon, S.T.; Coffey, S.; Bhindi, R.; Soo Hoo, S.Y.; Nelson, G.I.; Ward, M.R.; Hansen, P.S.; Asrress, K.N.; Chow, C.K.; Celermajer, D.S.; et al. Increasing proportion of ST elevation myocardial infarction patients with coronary atherosclerosis poorly explained by standard modifiable risk factors. Eur. J. Prev. Cardiol. 2017, 24, 1824-1830. [CrossRef]

16. Figtree, G.A.; Vernon, S.T.; Hadziosmanovic, N.; Sundström, J.; Alfredsson, J.; Arnott, C.; Delatour, V.; Leósdóttir, M.; Hagström, E. Mortality in STEMI patients without standard modifiable risk factors: A sex-disaggregated analysis of SWEDEHEART registry data. Lancet 2021, 397, 1085-1094. [CrossRef]

17. Kotseva, K.; Wood, D.; De Bacquer, D.; De Backer, G.; Rydén, L.; Jennings, C.; Gyberg, V.; Amouyel, P.; Bruthans, J.; Castro Conde, A.; et al. EUROASPIRE IV: A European Society of Cardiology survey on the lifestyle, risk factor and therapeutic management of coronary patients from 24 European countries. Eur. J. Prev. Cardiol. 2016, 23, 636-648. [CrossRef]

18. Piironen, M.; Ukkola, O.; Huikuri, H.; Havulinna, A.S.; Koukkunen, H.; Mustonen, J.; Ketonen, M.; Lehto, S.; Airaksinen, J.; Antero Kesäniemi, Y.; et al. Trends in long-term prognosis after acute coronary syndrome. Eur. J. Prev. Cardiol. 2017, 24, 274-280. [CrossRef]

19. Benjamin, E.J.; Muntner, P.; Alonso, A.; Bittencourt, M.S.; Callaway, C.W.; Carson, A.P.; Chamberlain, A.M.; Chang, A.R.; Cheng, S.; Das, S.R.; et al. Heart Disease and Stroke Statistics-2019 Update: A Report From the American Heart Association. Circulation 2019, 139, e56-e528. [CrossRef]

20. Steensma, D.P. Clinical consequences of clonal hematopoiesis of indeterminate potential. Blood Adv. 2018, 2, 3404-3410. [CrossRef]

21. Aviv, A.; Levy, D. Hemothelium, Clonal Hematopoiesis of Indeterminate Potential, and Atherosclerosis. Circulation 2019, 139, 7-9. [CrossRef]

22. Chiriacò, M.; Georgiopoulos, G.; Duranti, E.; Antonioli, L.; Puxeddu, I.; Nannipieri, M.; Rosada, J.; Blandizzi, C.; Taddei, S.; Virdis, A.; et al. Inflammation and Vascular Ageing: From Telomeres to Novel Emerging Mechanisms. High Blood. Press. Cardiovasc. Prev. 2019, 26, 321-329. [CrossRef]

23. Shay, J.W.; Wright, W.E. Telomeres and telomerase: Three decades of progress. Nat. Rev. Genet. 2019, 20, 299-309. [CrossRef]

24. Hackett, J.A.; Feldser, D.M.; Greider, C.W. Telomere dysfunction increases mutation rate and genomic instability. Cell 2001, 106, 275-286. [CrossRef]

25. Blackburn, E.H. Telomere states and cell fates. Nature 2000, 408, 53-56. [CrossRef]

26. Shay, J.W.; Wright, W.E. Role of telomeres and telomerase in cancer. Semin. Cancer Biol. 2011, 21, 349-353. [CrossRef]

27. Aviv, A.; Anderson, J.J.; Shay, J.W. Mutations, Cancer and the Telomere Length Paradox. Trends Cancer 2017, 3, 253-258. [CrossRef]

28. Daniali, L.; Benetos, A.; Susser, E.; Kark, J.D.; Labat, C.; Kimura, M.; Desai, K.K.; Granick, M.; Aviv, A. Telomeres shorten at equivalent rates in somatic tissues of adults. Nat. Commun. 2013, 4, 1-7. [CrossRef]

29. Wang, C.-Y. Asynchronous Shortening of Telomere Length and Cardiovascular Outcomes; American College of Cardiology Foundation: Washington, DC, USA, 2018.

30. Samani, N.J.; van der Harst, P. Biological ageing and cardiovascular disease. Heart 2008, 94, 537-539. [CrossRef] [PubMed]

31. Oeseburg, H.; de Boer, R.A.; van Gilst, W.H.; van der Harst, P. Telomere biology in healthy aging and disease. Pflugers Arch. 2010, 459, 259-268. [CrossRef]

32. Marioni, R.E.; Harris, S.E.; Shah, S.; McRae, A.F.; von Zglinicki, T.; Martin-Ruiz, C.; Wray, N.R.; Visscher, P.M.; Deary, I.J. The epigenetic clock and telomere length are independently associated with chronological age and mortality. Int. J. Epidemiol. 2016, 45, 424-432. [CrossRef]

33. Fasching, C.L. Telomere length measurement as a clinical biomarker of aging and disease. Crit. Rev. Clin. Lab. Sci. 2018, 55, 443-465. [CrossRef]

34. Lai, T.P.; Wright, W.E.; Shay, J.W. Comparison of telomere length measurement methods. Philos. Trans. R Soc. Lond. B Biol. Sci. 2018, 373, 20160451. [CrossRef]

35. Epel, E.S.; Merkin, S.S.; Cawthon, R.; Blackburn, E.H.; Adler, N.E.; Pletcher, M.J.; Seeman, T.E. The rate of leukocyte telomere shortening predicts mortality from cardiovascular disease in elderly men. Aging 2008, 1, 81-88. [CrossRef] [PubMed] 
36. D'Mello, M.J.; Ross, S.A.; Briel, M.; Anand, S.S.; Gerstein, H.; Paré, G. Association between shortened leukocyte telomere length and cardiometabolic outcomes: Systematic review and meta-analysis. Circ. Cardiovasc. Genet. 2015, 8, 82-90. [CrossRef]

37. Bekaert, S.; De Meyer, T.; Rietzschel, E.R.; De Buyzere, M.L.; De Bacquer, D.; Langlois, M.; Segers, P.; Cooman, L.; Van Damme, P.; Cassiman, P.; et al. Telomere length and cardiovascular risk factors in a middle-aged population free of overt cardiovascular disease. Aging Cell 2007, 6, 639-647. [CrossRef] [PubMed]

38. Fitzpatrick, A.L.; Kronmal, R.A.; Gardner, J.P.; Psaty, B.M.; Jenny, N.S.; Tracy, R.P.; Walston, J.; Kimura, M.; Aviv, A. Leukocyte telomere length and cardiovascular disease in the cardiovascular health study. Am. J. Epidemiol. 2007, 165, 14-21. [CrossRef]

39. Chen, W.D.; Wen, M.S.; Shie, S.S.; Lo, Y.L.; Wo, H.T.; Wang, C.C.; Hsieh, I.C.; Lee, T.H.; Wang, C.Y. The circadian rhythm controls telomeres and telomerase activity. Biochem. Biophys. Res. Commun. 2014, 451, 408-414. [CrossRef]

40. McAlpine, C.S.; Swirski, F.K. Circadian influence on metabolism and inflammation in atherosclerosis. Circ. Res. 2016, 119, 131-141. [CrossRef]

41. Egan, K.J.; Knutson, K.L.; Pereira, A.C.; von Schantz, M. The role of race and ethnicity in sleep, circadian rhythms and cardiovascular health. Sleep Med. Rev. 2017, 33, 70-78. [CrossRef]

42. Osum, M.; Serakinci, N. Impact of circadian disruption on health; SIRT1 and Telomeres. DNA Repair 2020, 96, 102993. [CrossRef]

43. Farzaneh-Far, R.; Lin, J.; Epel, E.S.; Harris, W.S.; Blackburn, E.H.; Whooley, M.A. Association of marine omega-3 fatty acid levels with telomeric aging in patients with coronary heart disease. JAMA 2010, 303, 250-257. [CrossRef]

44. Arsenis, N.C.; You, T.; Ogawa, E.F.; Tinsley, G.M.; Zuo, L. Physical activity and telomere length: Impact of aging and potential mechanisms of action. Oncotarget 2017, 8, 45008-45019. [CrossRef] [PubMed]

45. Gronek, P.; Wielinski, D.; Cyganski, P.; Rynkiewicz, A.; Zając, A.; Maszczyk, A.; Gronek, J.; Podstawski, R.; Czarny, W.; Balko, S.; et al. A Review of Exercise as Medicine in Cardiovascular Disease: Pathology and Mechanism. Aging Dis. 2020, 11, 327-340. [CrossRef]

46. Calvert, P.A.; Liew, T.V.; Gorenne, I.; Clarke, M.; Costopoulos, C.; Obaid, D.R.; O'Sullivan, M.; Shapiro, L.M.; McNab, D.C.; Densem, C.G.; et al. Leukocyte telomere length is associated with high-risk plaques on virtual histology intravascular ultrasound and increased proinflammatory activity. Arterioscler. Thromb. Vasc. Biol. 2011, 31, 2157-2164. [CrossRef] [PubMed]

47. Armstrong, E.J.; Xing, L.; Zhang, J.; Zheng, Y.; Shunk, K.A.; Yeh, R.W.; Farzaneh-Far, R.; Yu, B.; Jang, I.K. Association between leukocyte telomere length and drug-eluting stent strut coverage by optical coherence tomography. J. Am. Coll. Cardiol. 2012, 59, 2218-2219. [CrossRef]

48. Leri, A.; Franco, S.; Zacheo, A.; Barlucchi, L.; Chimenti, S.; Limana, F.; Nadal-Ginard, B.; Kajstura, J.; Anversa, P.; Blasco, M.A. Ablation of telomerase and telomere loss leads to cardiac dilatation and heart failure associated with p53 upregulation. EMBO J. 2003, 22, 131-139. [CrossRef]

49. Haver, V.G.; Mateo Leach, I.; Kjekshus, J.; Fox, J.C.; Wedel, H.; Wikstrand, J.; de Boer, R.A.; van Gilst, W.H.; McMurray, J.J.; van Veldhuisen, D.J. Telomere length and outcomes in ischaemic heart failure: Data from the COntrolled ROsuvastatin multiNAtional Trial in Heart Failure (CORONA). Eur. J. Heart Fail. 2015, 17, 313-319. [CrossRef]

50. van der Harst, P.; van der Steege, G.; de Boer, R.A.; Voors, A.A.; Hall, A.S.; Mulder, M.J.; van Gilst, W.H.; van Veldhuisen, D.J.; Group, M.-H.S. Telomere length of circulating leukocytes is decreased in patients with chronic heart failure. J. Am. Coll. Cardiol. 2007, 49, 1459-1464. [CrossRef] [PubMed]

51. Samper, E.; Flores, J.M.; Blasco, M.A. Restoration of telomerase activity rescues chromosomal instability and premature aging in Terc $^{-/-}$mice with short telomeres. EMBO Rep. 2001, 2, 800-807. [CrossRef] [PubMed]

52. Zhu, Y.; Liu, X.; Ding, X.; Wang, F.; Geng, X. Telomere and its role in the aging pathways: Telomere shortening, cell senescence and mitochondria dysfunction. Biogerontology 2019, 20, 1-16. [CrossRef]

53. de Punder, K.; Heim, C.; Wadhwa, P.D.; Entringer, S. Stress and immunosenescence: The role of telomerase. Psychoneuroendocrinology 2019, 101, 87-100. [CrossRef]

54. Liu, T.; Yu, H.; Ding, L.; Wu, Z.; Gonzalez De Los Santos, F.; Liu, J.; Ullenbruch, M.; Hu, B.; Martins, V.; Phan, S.H. Conditional Knockout of Telomerase Reverse Transcriptase in Mesenchymal Cells Impairs Mouse Pulmonary Fibrosis. PLoS ONE 2015, 10, e0142547. [CrossRef] [PubMed]

55. Poch, E.; Carbonell, P.; Franco, S.; Díez-Juan, A.; Blasco, M.A.; Andrés, V. Short telomeres protect from diet-induced atherosclerosis in apolipoprotein E-null mice. FASEB J. 2004, 18, 418-420. [CrossRef]

56. Meyer, T.D.; Nawrot, T.; Bekaert, S.; Buyzere, M.L.D.; Rietzschel, E.R.; Andrés, V. Telomere Length as Cardiovascular Aging Biomarker. J. Am. Coll. Cardiol. 2018, 72, 805-813. [CrossRef]

57. Bernardes de Jesus, B.; Vera, E.; Schneeberger, K.; Tejera, A.M.; Ayuso, E.; Bosch, F.; Blasco, M.A. Telomerase gene therapy in adult and old mice delays aging and increases longevity without increasing cancer. EMBO Mol. Med. 2012, 4, 691-704. [CrossRef]

58. Bär, C.; Bernardes de Jesus, B.; Serrano, R.; Tejera, A.; Ayuso, E.; Jimenez, V.; Formentini, I.; Bobadilla, M.; Mizrahi, J.; de Martino, A.; et al. Telomerase expression confers cardioprotection in the adult mouse heart after acute myocardial infarction. Nat. Commun. 2014, 5, 5863. [CrossRef]

59. Ramunas, J.; Yakubov, E.; Brady, J.J.; Corbel, S.Y.; Holbrook, C.; Brandt, M.; Stein, J.; Santiago, J.G.; Cooke, J.P.; Blau, H.M. Transient delivery of modified mRNA encoding TERT rapidly extends telomeres in human cells. FASEB J. 2015, 29, 1930-1939. [CrossRef]

60. Wang, C.Y.; Liu, P.Y.; Liao, J.K. Pleiotropic effects of statin therapy: Molecular mechanisms and clinical results. Trends. Mol. Med. 2008, 14, 37-44. [CrossRef] 
61. Tran, P.T.; Meeker, A.K.; Platz, E.A. Association between statin drug use and peripheral blood leukocyte telomere length in the National Health and Nutrition Examination Survey 1999-2002: A cross-sectional study. Ann. Epidemiol. 2018, $28,529-534$. [CrossRef] [PubMed]

62. Spyridopoulos, I.; Haendeler, J.; Urbich, C.; Brummendorf, T.H.; Oh, H.; Schneider, M.D.; Zeiher, A.M.; Dimmeler, S. Statins enhance migratory capacity by upregulation of the telomere repeat-binding factor TRF2 in endothelial progenitor cells. Circulation 2004, 110, 3136-3142. [CrossRef]

63. Imanishi, T.; Tsujioka, H.; Akasaka, T. Endothelial progenitor cells dysfunction and senescence: Contribution to oxidative stress. Curr. Cardiol. Rev. 2008, 4, 275-286. [CrossRef]

64. Donnini, S.; Terzuoli, E.; Ziche, M.; Morbidelli, L. Sulfhydryl angiotensin-converting enzyme inhibitor promotes endothelial cell survival through nitric-oxide synthase, fibroblast growth factor-2, and telomerase cross-talk. J. Pharmacol. Exp. Ther. 2010, 332, 776-784. [CrossRef]

65. Sheng, R.; Gu, Z.L.; Xie, M.L. Epigallocatechin gallate, the major component of polyphenols in green tea, inhibits telomere attrition mediated cardiomyocyte apoptosis in cardiac hypertrophy. Int. J. Cardiol. 2013, 162, 199-209. [CrossRef]

66. Makino, N.; Maeda, T.; Oyama, J.; Higuchi, Y.; Mimori, K. Improving insulin sensitivity via activation of PPAR-gamma increases telomerase activity in the heart of OLETF rats. Am. J. Physiol. Heart Circ. Physiol. 2009, 297, H2188-H2195. [CrossRef]

67. Werner, C.; Gensch, C.; Pöss, J.; Haendeler, J.; Böhm, M.; Laufs, U. Pioglitazone activates aortic telomerase and prevents stress-induced endothelial apoptosis. Atherosclerosis 2011, 216, 23-34. [CrossRef] [PubMed]

68. Imanishi, T.; Kobayashi, K.; Kuroi, A.; Ikejima, H.; Akasaka, T. Pioglitazone inhibits angiotensin II-induced senescence of endothelial progenitor cell. Hypertens. Res. 2008, 31, 757-765. [CrossRef]

69. Bernardes de Jesus, B.; Schneeberger, K.; Vera, E.; Tejera, A.; Harley, C.B.; Blasco, M.A. The telomerase activator TA-65 elongates short telomeres and increases health span of adult/old mice without increasing cancer incidence. Aging Cell 2011, 10, 604-621. [CrossRef]

70. Salvador, L.; Singaravelu, G.; Harley, C.B.; Flom, P.; Suram, A.; Raffaele, J.M. A Natural Product Telomerase Activator Lengthens Telomeres in Humans: A Randomized, Double Blind, and Placebo Controlled Study. Rejuvenation Res. 2016, 19, 478-484. [CrossRef] [PubMed]

71. Fernandez, M.L.; Thomas, M.S.; Lemos, B.S.; DiMarco, D.M.; Missimer, A.; Melough, M.; Chun, O.K.; Murillo, A.G.; Alyousef, H.M.; Medina-Vera, I. TA-65, A Telomerase Activator improves Cardiovascular Markers in Patients with Metabolic Syndrome. Curr. Pharm. Des. 2018, 24, 1905-1911. [CrossRef]

72. Grossmann, M. Danazol Treatment for Telomere Diseases. N. Engl. J. Med. 2016, 375, 1095. [CrossRef]

73. Ziegler, P.; Schrezenmeier, H.; Akkad, J.; Brassat, U.; Vankann, L.; Panse, J.; Wilop, S.; Balabanov, S.; Schwarz, K.; Martens, U.M.; et al. Telomere elongation and clinical response to androgen treatment in a patient with aplastic anemia and a heterozygous hTERT gene mutation. Ann. Hematol. 2012, 91, 1115-1120. [CrossRef]

74. Libby, P.; Sidlow, R.; Lin, A.E.; Gupta, D.; Jones, L.W.; Moslehi, J.; Zeiher, A.; Jaiswal, S.; Schulz, C.; Blankstein, R.; et al. Clonal Hematopoiesis: Crossroads of Aging, Cardiovascular Disease, and Cancer: JACC Review Topic of the Week. J. Am. Coll. Cardiol. 2019, 74, 567-577. [CrossRef]

75. Jaiswal, S.; Ebert, B.L. Clonal hematopoiesis in human aging and disease. Science 2019, 366. [CrossRef]

76. Zink, F.; Stacey, S.N.; Norddahl, G.L.; Frigge, M.L.; Magnusson, O.T.; Jonsdottir, I.; Thorgeirsson, T.E.; Sigurdsson, A.; Gudjonsson, S.A.; Gudmundsson, J.; et al. Clonal hematopoiesis, with and without candidate driver mutations, is common in the elderly. Blood 2017, 130, 742-752. [CrossRef]

77. Jaiswal, S.; Natarajan, P.; Silver, A.J.; Gibson, C.J.; Bick, A.G.; Shvartz, E.; McConkey, M.; Gupta, N.; Gabriel, S.; Ardissino, D.; et al. Clonal Hematopoiesis and Risk of Atherosclerotic Cardiovascular Disease. N. Engl. J. Med. 2017, 377, 111-121. [CrossRef]

78. Atherosclerosis, T.; Vascular Biology Italian Study, G. No evidence of association between prothrombotic gene polymorphisms and the development of acute myocardial infarction at a young age. Circulation 2003, 107, 1117-1122. [CrossRef]

79. Saleheen, D.; Zaidi, M.; Rasheed, A.; Ahmad, U.; Hakeem, A.; Murtaza, M.; Kayani, W.; Faruqui, A.; Kundi, A.; Zaman, K.S.; et al. The Pakistan Risk of Myocardial Infarction Study: A resource for the study of genetic, lifestyle and other determinants of myocardial infarction in South Asia. Eur. J. Epidemiol. 2009, 24, 329-338. [CrossRef]

80. Do, R.; Stitziel, N.O.; Won, H.H.; Jørgensen, A.B.; Duga, S.; Angelica Merlini, P.; Kiezun, A.; Farrall, M.; Goel, A.; Zuk, O.; et al. Exome sequencing identifies rare LDLR and APOA5 alleles conferring risk for myocardial infarction. Nature 2015, 518, 102-106. [CrossRef] [PubMed]

81. Strom, S.P. Current practices and guidelines for clinical next-generation sequencing oncology testing. Cancer Biol. Med. 2016, 13, 3-11. [CrossRef]

82. Dorsheimer, L.; Assmus, B.; Rasper, T.; Ortmann, C.A.; Ecke, A.; Abou-El-Ardat, K.; Schmid, T.; Brune, B.; Wagner, S.; Serve, H.; et al. Association of Mutations Contributing to Clonal Hematopoiesis With Prognosis in Chronic Ischemic Heart Failure. JAMA Cardiol. 2019, 4, 25-33. [CrossRef]

83. Pascual-Figal, D.A.; Bayes-Genis, A.; Díez-Díez, M.; Hernández-Vicente, Á.; Vázquez-Andrés, D.; de la Barrera, J.; Vazquez, E.; Quintas, A.; Zuriaga, M.A.; Asensio-López, M.C.; et al. Clonal Hematopoiesis and Risk of Progression of Heart Failure With Reduced Left Ventricular Ejection Fraction. J. Am. Coll. Cardiol. 2021, 77, 1747-1759. [CrossRef] [PubMed]

84. Palomo, L.; Santiago-Vacas, E.; Pascual-Figal, D.; Fuster, J.J.; Solé, F.; Bayés-Genís, A. Prevalence and characteristics of clonal hematopoiesis in heart failure. Rev. Esp. Cardiol. 2021, S1885-S5857. [CrossRef] 
85. Hasin, T.; Gerber, Y.; McNallan, S.M.; Weston, S.A.; Kushwaha, S.S.; Nelson, T.J.; Cerhan, J.R.; Roger, V.L. Patients with heart failure have an increased risk of incident cancer. J. Am. Coll. Cardiol. 2013, 62, 881-886. [CrossRef] [PubMed]

86. Mas-Peiro, S.; Hoffmann, J.; Fichtlscherer, S.; Dorsheimer, L.; Rieger, M.A.; Dimmeler, S.; Vasa-Nicotera, M.; Zeiher, A.M. Clonal haematopoiesis in patients with degenerative aortic valve stenosis undergoing transcatheter aortic valve implantation. Eur. Heart J. 2020, 41, 933-939. [CrossRef]

87. Fuster, J.J.; Walsh, K. Somatic Mutations and Clonal Hematopoiesis: Unexpected Potential New Drivers of Age-Related Cardiovascular Disease. Circ. Res. 2018, 122, 523-532. [CrossRef]

88. Fuster, J.J.; MacLauchlan, S.; Zuriaga, M.A.; Polackal, M.N.; Ostriker, A.C.; Chakraborty, R.; Wu, C.L.; Sano, S.; Muralidharan, S.; Rius, C.; et al. Clonal hematopoiesis associated with TET2 deficiency accelerates atherosclerosis development in mice. Science 2017, 355, 842-847. [CrossRef]

89. Sano, S.; Oshima, K.; Wang, Y.; MacLauchlan, S.; Katanasaka, Y.; Sano, M.; Zuriaga, M.A.; Yoshiyama, M.; Goukassian, D.; Cooper, M.A.; et al. Tet2-Mediated Clonal Hematopoiesis Accelerates Heart Failure Through a Mechanism Involving the IL-1 $\beta / N L R P 3$ Inflammasome. J. Am. Coll. Cardiol. 2018, 71, 875-886. [CrossRef]

90. Wang, Y.; Sano, S.; Yura, Y.; Ke, Z.; Sano, M.; Oshima, K.; Ogawa, H.; Horitani, K.; Min, K.D.; Miura-Yura, E.; et al. Tet2mediated clonal hematopoiesis in nonconditioned mice accelerates age-associated cardiac dysfunction. JCI Insight 2020, 5, e135204. [CrossRef] [PubMed]

91. Fuster, J.J.; Zuriaga, M.A.; Zorita, V.; MacLauchlan, S.; Polackal, M.N.; Viana-Huete, V.; Ferrer-Pérez, A.; Matesanz, N.; HerreroCervera, A.; Sano, S.; et al. TET2-Loss-of-Function-Driven Clonal Hematopoiesis Exacerbates Experimental Insulin Resistance in Aging and Obesity. Cell Rep. 2020, 33, 108326. [CrossRef]

92. Grebe, A.; Hoss, F.; Latz, E. NLRP3 Inflammasome and the IL-1 Pathway in Atherosclerosis. Circ. Res. 2018, 122, 1722-1740. [CrossRef]

93. Libby, P. Interleukin-1 Beta as a Target for Atherosclerosis Therapy: Biological Basis of CANTOS and Beyond. J. Am. Coll. Cardiol. 2017, 70, 2278-2289. [CrossRef]

94. Ridker, P.M.; Everett, B.M.; Thuren, T.; MacFadyen, J.G.; Chang, W.H.; Ballantyne, C.; Fonseca, F.; Nicolau, J.; Koenig, W.; Anker, S.D.; et al. Antiinflammatory Therapy with Canakinumab for Atherosclerotic Disease. N. Engl. J. Med. 2017, 377, 1119-1131. [CrossRef]

95. Tardif, J.C.; Kouz, S.; Waters, D.D.; Bertrand, O.F.; Diaz, R.; Maggioni, A.P.; Pinto, F.J.; Ibrahim, R.; Gamra, H.; Kiwan, G.S.; et al. Efficacy and Safety of Low-Dose Colchicine after Myocardial Infarction. N. Engl. J. Med. 2019, 381, 2497-2505. [CrossRef]

96. Sano, S.; Oshima, K.; Wang, Y.; Katanasaka, Y.; Sano, M.; Walsh, K. CRISPR-Mediated Gene Editing to Assess the Roles of Tet2 and Dnmt3a in Clonal Hematopoiesis and Cardiovascular Disease. Circ. Res. 2018, 123, 335-341. [CrossRef] [PubMed]

97. Leoni, C.; Montagner, S.; Rinaldi, A.; Bertoni, F.; Polletti, S.; Balestrieri, C.; Monticelli, S. Dnmt3a restrains mast cell inflammatory responses. Proc. Natl. Acad. Sci. USA 2017, 114, E1490-E1499. [CrossRef] [PubMed]

98. Gamper, C.J.; Agoston, A.T.; Nelson, W.G.; Powell, J.D. Identification of DNA methyltransferase 3a as a T cell receptor-induced regulator of Th1 and Th2 differentiation. J. Immunol. 2009, 183, 2267-2276. [CrossRef] [PubMed]

99. Abplanalp, W.T.; Cremer, S.; John, D.; Hoffmann, J.; Schuhmacher, B.; Merten, M.; Rieger, M.A.; Vasa-Nicotera, M.; Zeiher, A.M.; Dimmeler, S. Clonal Hematopoiesis-Driver DNMT3A Mutations Alter Immune Cells in Heart Failure. Circ. Res. 2021, 128, 216-228. [CrossRef] [PubMed]

100. Campbell, P.J.; Green, A.R. The myeloproliferative disorders. N. Engl. J. Med. 2006, 355, 2452-2466. [CrossRef]

101. Moliterno, A.R.; Hankins, W.D.; Spivak, J.L. Impaired expression of the thrombopoietin receptor by platelets from patients with polycythemia vera. N. Engl. J. Med. 1998, 338, 572-580. [CrossRef]

102. Campbell, P.J.; Scott, L.M.; Buck, G.; Wheatley, K.; East, C.L.; Marsden, J.T.; Duffy, A.; Boyd, E.M.; Bench, A.J.; Scott, M.A.; et al Definition of subtypes of essential thrombocythaemia and relation to polycythaemia vera based on JAK2 V617F mutation status: A prospective study. Lancet 2005, 366, 1945-1953. [CrossRef]

103. Kjær, L. Clonal Hematopoiesis and Mutations of Myeloproliferative Neoplasms. Cancers 2020, 12, 2100. [CrossRef]

104. Sano, S.; Wang, Y.; Yura, Y.; Sano, M.; Oshima, K.; Yang, Y.; Katanasaka, Y.; Min, K.D.; Matsuura, S.; Ravid, K.; et al. JAK2 (V617F) -Mediated Clonal Hematopoiesis Accelerates Pathological Remodeling in Murine Heart Failure. JACC Basic Transl. Sci. 2019, 4, 684-697. [CrossRef]

105. Tang, Y.; Liu, W.; Wang, W.; Fidler, T.; Woods, B.; Levine, R.L.; Tall, A.R.; Wang, N. Inhibition of JAK2 Suppresses Myelopoiesis and Atherosclerosis in Apoe(-/-) Mice. Cardiovasc. Drugs Ther. 2020, 34, 145-152. [CrossRef]

106. Wang, W.; Liu, W.; Fidler, T.; Wang, Y.; Tang, Y.; Woods, B.; Welch, C.; Cai, B.; Silvestre-Roig, C.; Ai, D.; et al. Macrophage Inflammation, Erythrophagocytosis, and Accelerated Atherosclerosis in Jak2 (V617F) Mice. Circ. Res. 2018, 123, e35-e47. [CrossRef] [PubMed]

107. Fidler, T.P.; Xue, C.; Yalcinkaya, M.; Hardaway, B.; Abramowicz, S.; Xiao, T.; Liu, W.; Thomas, D.G.; Hajebrahimi, M.A.; Pircher, J.; et al. The AIM2 inflammasome exacerbates atherosclerosis in clonal haematopoiesis. Nature 2021, 592, 296-301. [CrossRef]

108. Vannucchi, A.M.; Kiladjian, J.J.; Griesshammer, M.; Masszi, T.; Durrant, S.; Passamonti, F.; Harrison, C.N.; Pane, F.; Zachee, P.; Mesa, R.; et al. Ruxolitinib versus standard therapy for the treatment of polycythemia vera. N. Engl. J. Med. 2015, 372, 426-435. [CrossRef]

109. Marchioli, R.; Finazzi, G.; Specchia, G.; Cacciola, R.; Cavazzina, R.; Cilloni, D.; De Stefano, V.; Elli, E.; Iurlo, A.; Latagliata, R.; et al. Cardiovascular events and intensity of treatment in polycythemia vera. N. Engl. J. Med. 2013, 368, 22-33. [CrossRef] 
110. Fujino, T.; Goyama, S.; Sugiura, Y.; Inoue, D.; Asada, S.; Yamasaki, S.; Matsumoto, A.; Yamaguchi, K.; Isobe, Y.; Tsuchiya, A.; et al. Mutant ASXL1 induces age-related expansion of phenotypic hematopoietic stem cells through activation of Akt/mTOR pathway. Nat. Commun. 2021, 12, 1826. [CrossRef]

111. Siegmund, S.E.; Yang, H.; Sharma, R.; Javors, M.; Skinner, O.; Mootha, V.; Hirano, M.; Schon, E.A. Low-dose rapamycin extends lifespan in a mouse model of mtDNA depletion syndrome. Hum. Mol. Genet. 2017, 26, 4588-4605. [CrossRef]

112. Sánchez-Cabo, F.; Fuster, J.J. Clonal haematopoiesis and atherosclerosis: A chicken or egg question? Nat. Rev. Cardiol. 2021, 18, 463-464. [CrossRef]

113. Agathocleous, M.; Meacham, C.E.; Burgess, R.J.; Piskounova, E.; Zhao, Z.; Crane, G.M.; Cowin, B.L.; Bruner, E.; Murphy, M.M.; Chen, W.; et al. Ascorbate regulates haematopoietic stem cell function and leukaemogenesis. Nature 2017, 549, 476-481. [CrossRef]

114. Dawoud, A.A.Z.; Tapper, W.J.; Cross, N.C.P. Clonal myelopoiesis in the UK Biobank cohort: ASXL1 mutations are strongly associated with smoking. Leukemia 2020, 34, 2660-2672. [CrossRef]

115. Tuke, M.; Tyrrell, J.; Ruth, K.S.; Beaumont, R.N.; Wood, A.R.; Murray, A.; Frayling, T.M.; Weedon, M.N.; Wright, C.F. Large Copy-Number Variants in UK Biobank Caused by Clonal Hematopoiesis May Confound Penetrance Estimates. Am. J. Hum. Genet. 2020, 107, 325-329. [CrossRef]

116. Honigberg, M.C.; Zekavat, S.M.; Niroula, A.; Griffin, G.K.; Bick, A.G.; Pirruccello, J.P.; Nakao, T.; Whitsel, E.A.; Farland, L.V.; Laurie, C.; et al. Premature Menopause, Clonal Hematopoiesis, and Coronary Artery Disease in Postmenopausal Women. Circulation 2021, 143, 410-423. [CrossRef]

117. Bick, A.G.; Popadin, K.; Thorball, C.W.; Uddin, M.M.; Zanni, M.; Yu, B.; Cavassini, M.; Rauch, A.; Tarr, P.; Schmid, P.; et al. Increased CHIP Prevalence Amongst People Living with HIV. medRxiv 2020. [CrossRef]

118. Hayden, K.M.; Leng, X.I.; Manson, J.E.; Desai, P.; Kitzman, J.; Jaiswal, S.; Whitsel, E.A.; Reiner, A.P. Clonal Hematopoiesis of indeterminate potential and the risk of mild cognitive impairment or probable dementia in the Women's Health Initiative Memory Study: Epidemiology/Risk and protective factors in MCI and dementia. Alzheimer's Dement. 2020, 16, e039121. [CrossRef]

119. Cochran, J.N.; Geier, E.G.; Bonham, L.W.; Newberry, J.S.; Amaral, M.D.; Thompson, M.L.; Lasseigne, B.N.; Karydas, A.M.; Roberson, E.D.; Cooper, G.M.; et al. Non-coding and Loss-of-Function Coding Variants in TET2 are Associated with Multiple Neurodegenerative Diseases. Am. J. Hum. Genet. 2020, 106, 632-645. [CrossRef] [PubMed]

120. Dawber, T.R.; Moore, F.E.; Mann, G.V. Coronary heart disease in the Framingham study. Am. J. Public Health Nations Health 1957, 47, 4-24. [CrossRef]

121. Vernon, S.T.; Coffey, S.; D’Souza, M.; Chow, C.K.; Kilian, J.; Hyun, K.; Shaw, J.A.; Adams, M.; Roberts-Thomson, P.; Brieger D.; et al. ST-Segment-Elevation Myocardial Infarction (STEMI) Patients Without Standard Modifiable Cardiovascular Risk Factors-How Common Are They, and What Are Their Outcomes? J. Am. Heart Assoc. 2019, 8, e013296. [CrossRef]

122. Silver, A.J.; Bick, A.G.; Savona, M.R. Germline risk of clonal haematopoiesis. Nat. Rev. Genet. 2021, 6, 1-15. [CrossRef]

123. Bick, A.G.; Weinstock, J.S.; Nandakumar, S.K.; Fulco, C.P.; Bao, E.L.; Zekavat, S.M.; Szeto, M.D.; Liao, X.; Leventhal, M.J.; Nasser, J. Inherited causes of clonal haematopoiesis in 97,691 whole genomes. Nature 2020, 586, 763-768. [CrossRef]

124. Mangaonkar, A.A.; Patnaik, M.M. Short Telomere Syndromes in Clinical Practice: Bridging Bench and Bedside. Mayo. Clin. Proc. 2018, 93, 904-916. [CrossRef] [PubMed]

125. Mitchell, J.R.; Wood, E.; Collins, K. A telomerase component is defective in the human disease dyskeratosis congenita. Nature 1999, 402, 551-555. [CrossRef]

126. Perdigones, N.; Perin, J.C.; Schiano, I.; Nicholas, P.; Biegel, J.A.; Mason, P.J.; Babushok, D.V.; Bessler, M. Clonal hematopoiesis in patients with dyskeratosis congenita. Am. J. Hematol. 2016, 91, 1227-1233. [CrossRef]

127. Karol, M.H. How environmental agents influence the aging process. Biomol. Ther. 2009, 17, 113-124. [CrossRef] 